\title{
Does Green Practices in the Hotel Attract Customer to Revisit? A Study in Green Hotel in Surakarta
}

\author{
Yuni Ermawati ${ }^{1}$, Septin Puji Astuti ${ }^{\varpi 1,2}$ \\ Departement of Shariah Business and Management, Faculty of Islamic Business and Economic, IAIN \\ Surakarta, Indonesia ${ }^{1}$ \\ Centre for Science and Technology, IAIN Surakarta, Indonesia ${ }^{2}$
}

\section{Article Information \\ Article History: \\ Received January 2020 \\ Approved February 2020 \\ Published June 2020}

\section{Keywords:}

Green hotel, Rumah Turi, tourism, moderating multiple regression analysis, revisit intention, service quality, facility, price.

\begin{abstract}
The Ministry of Environment of the Republic of Indonesia encourages sustainable tourism and hospitality industry to achieve green hotel and green tourism in 2020. Rumah Turi as one of hotel destinations in the middle of Surakarta has provided green practice and facilities in the hotel. This study intends to investigate the determinant factors of revisit intention to Rumah Turi. This study is conducted to hotel customers who have visited Rumah Turi. Sample of this study is 131 customers of Rumah Turi from various cities in Indonesia. Five independent variables, i.e. green practice, service quality, facility, price and location, are applied in this study to be identified of their influence to revisit intention. By implementing linear multiple regression analysis, it is found that this study unable to make evidence that service quality and price influence customer to have the intention to revisit Rumah Turi. However, by using moderated multiple regression analysis, this study has proven three models of the determinant factors of revisit intention. The first model (Model 3) is, the moderator of service quality to facility and the moderator of price to location, in addition to green practice have significantly influenced revisit intention. Second model is Model 4 , where green service and service quality are the moderators of facility and price as the moderator of location have significantly influenced to revisit intention. Third model is Model 5, where service quality, price and green practice are the moderators of facility altogether with location have significantly influenced revisit intention.
\end{abstract}

\section{INTRODUCTION}

During 2015 and 2017, Indonesian tourists has elevated from 252.4 million to 270.8 million tourists (Reagan et al., 2018). This improves economic development. On the other hand, tourism and hospitality industries have a contribution to environmental degradation. The transportation from the original location to tourism destination that may affect air quality, the building in the tourism location and human activities in the area of tourism and accommodation may affect ecology quality. Hence, the Ministry of Environment the Republic of Indonesia encourages tourism and hospitality industry to reduce environmental degradation through green building and green tourism that should be achieved in 2030 (Said et al., 2016).
Hotel as one of the destinations of tourism and hospitality was also encouraged to be operated through eco-friendly management. By running the hotel with green practices, the hotel will have an opportunity to save millions of dollars (Baker et al., 2013). The implementation of resource reduction, energy saving and water efficiency are such causes of efficiency improvement in the hotel (Han, 2015)

In addition to the government, awareness from hotel management led the hotel to provide environmentally conscious hospitality services to the customers (Chan, 2014; Deraman et al., 2017; Lee et al., 2010). In the worldwide, there is an increase in awareness of hotel managers to incorporate environmental activities in the hotel. Hotel managers understand that developing services and products that do not harm human health and

\footnotetext{
Correspondence Address:

L2 Building, 1st Floor, Faculty of Economics, Universitas Negeri Semarang

Jalan Taman Siswa, Sekaran, Gunungpati, Semarang, 50229

E-mail: septin.astuti@gmail.com
} 
environment in the hotel through green marketing give more benefit to the performance of the hotel (Graci \& Dodds, 2008). It elevates green hotel image (Chan, 2013) even though there was a lack of understanding of how to practice environmental activities in the hotel industry (Al-aomar \& Hussain, 2017). Consequently, the implementation of green practice in the hotel was varied from high to low (Alonso-almeida et al., 2016).

Some scholars have proven that the implementation of eco-hotel attracts people to visit intention hotel (Colby et al., 2000; Han et al., 2009). It also influences loyalty of the customers because there are satisfied to green service in the hotel.

Generally, more scholars have high intention to focus on the theory of planned behavior (TPB) and psychographic attributes to identify the decision of costumer to visit hotel (Chen et al., 2016; Kiatkawsin \& Han, 2017; Nimri et al., 2017; Verma \& Chandra, 2018). Some others have found that environmentally conscious consumer is more likely to seek high quality of environmentally product instead of price (Souza, 2007; Baker et al., 2013). The costumers who implemented environmental friendly activities at home have a close relation to the decision to purchase green hotel (Millar, 2009; Han \& Jin, 2015).

However, there are also some pieces of evidence that environmental attributes in the hotel do not determine customer's intention to visit. Kasim (2004) has shown that more customers tend to choose a hotel based on price and service quality rather than environmental attributes. Meanwhile, $\mathrm{Hu}$ et al. (2019) study found that quality of service is the attributed complained by the high rate hotel customers, whilst low rate hotel customers were complaining about facility provided by the hotel. In addition to the quality of services, location is the competitive advantage of the hotel (Adam \& Amuquandoh, 2013). However, the price of the room is more expensive if the hotel located surrounding the tourism area such as city centre (Valentin \& Neill, 2018) and the beach (Rigall-i-torrent et al., 2011).

Location of the hotel attracts customer intention to visit. A hotel which is located near the centre of tourism destination such as city centre, heritage centre, or beach is more attracted customer intention to visit. Easy to access, availability of transportation and parking are also determinant factors of hotel consumer to visit (Fang et al., 2019). Study of Saló et al. (2014) shows that location is one of the public attributes of the hotel that influence customer decision to purchase.

In some studies, in general, price affects the decision to visit a hotel (Njite et al., 2017). However, a green hotel usually charges more expensive
(Rahman \& Reynolds, 2016) due to its advantages on environmental services. Moreover, the facility of the hotel is essential for hotel customer ( $\mathrm{Hu}$ et al., 2019). But, the luxury facility may increase the price. Similarly, hotel location also determines the price of the room (Rigall-i-torrent et al., 2011; Masiero et al., 2019; Chica-olmo et al., 2020). The closer location to the hotel to the tourism destination, the hotel room will be more expensive.

Understanding customers perception of the hotel performance improves customer loyalty (Chan, 2014). Revisit is an indication of loyalty (Kandampully \& Suhartanto, 2000). Therefore, green hotel managers should understand the driving factors of customer to visit or revisit in order to improve costumers visits. Hence, this study intends to investigate the determinant factor of green hotel revisit in Surakarta.

Surakarta, which is one of the centre of Javanese heritage culture, has 165 hotels in 2018 which has an occupancy rate of 46.25 by 2018 (BPS Kota Surakarta, 2018). This study will be conducted for Rumah Turi Hotel. Rumah Turi is one of the hotels which is located in the middle of Surakarta. This hotel was built as an eco-friendly hotel. Some evidence shows that this hotel has meet eco-design building (Soegijanto, 2014), implemented water conservation (Arafat \& Syamsiyah, 2013).

\section{Hypotheses Development}

The hotel is recognised as a green hotel when it conducted energy conservation, practising sustainable management such as recycling, reusing and resource saving (Hsiao et al., 2014). Eco label of the hotel influences the customer's decision to visit, even some of the customers ignore the price and quality (Chan, 2014). Studies have proven that willingness to pay more to green hotel influences to visit green hotel (Han et al., 2009). Green attributes such as recycling, bin and energy saving lighting were more preferred by the hotel costumers (Millar \& Baloglu, 2008; Millar $t$ al., 2012). This is why the marketers of a green hotel should promote their environmental practices provided by the hotel to attract green consumer to visit the hotel (Han et al., 2009).

Generally, service quality is prominent for service industries such as a hotel (Hu et al., 2019). It is the main determinant of customer satisfaction (Hu et al., 2019) which in turns affect the repurchase intention (Han et al., 2011; Perera \& Vlosky, 2013). Scholars have also proved prominent of service quality by the customers that is applied for a green hotel as well (Han \& Kim, 2010; Merli et al., 2019). Environmental attributes are fundamental to a green hotel, and it should be incorporated 
into service quality (Robinot \& Gionnelloni, 2010) to improve customer intention to visit. There is evidence in China that customer satisfaction is influenced by the moderating effect of green practice to service quality (Lee et al., 2018).

Due to those fundamental reviews, this study identifies the determinant of repurchase intention to green hotel. Five models will be tested in this study are:

Model 1: The influence of service quality, facility, price, location and green practice to revisit intention. The relationship of this model is model is depicted in Figure 1. The equation for this model is: $f(y)=f\left(x_{-} q, x_{-} f, x_{-} p, x_{-}, x_{-} g\right)$

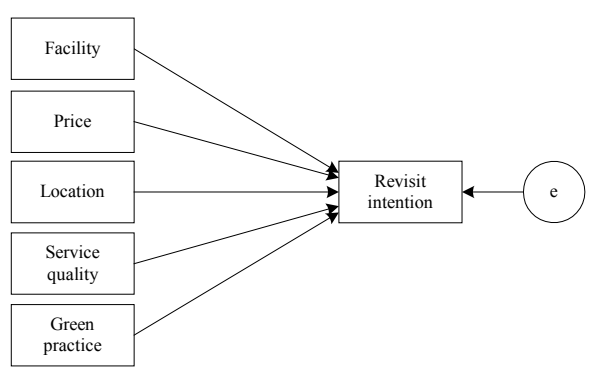

Figure 1. Model 1

Model 2: The influence of facility moderated by service quality, location and green practice to revisit intention, which is depicted in Figure 2. The equation for this model is: $f(y)=f\left(x_{-} f q, x_{-}, x_{-} g\right)$

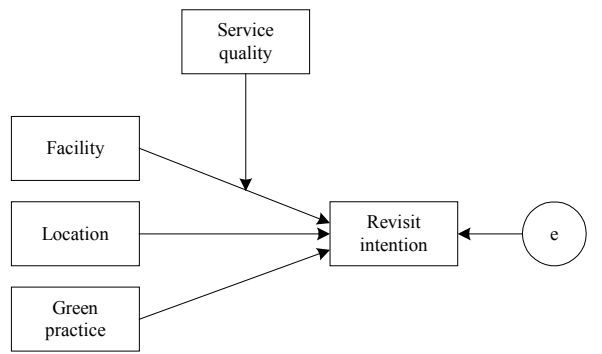

Figure 2. Model 2

Model 3: The influence of facility moderated by service quality, location moderated by price and green practice to revisit intention. Figure 3 shows the relationship of this model. The equation for this model is: $f(y)=f\left(x_{-} f q, x_{-} l p, x_{-} g\right)$

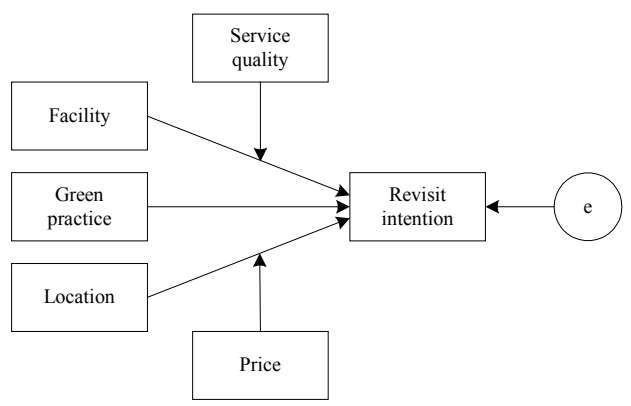

Figure 3. Model 3
Model 4: The influence of facility moderated by service quality and green practice, location moderated by price to revisit intention. The model is depicted in Figure 4, whilst the equation for this model is: $f(y)=f\left(x_{-} f q g, x_{-} l p\right)$

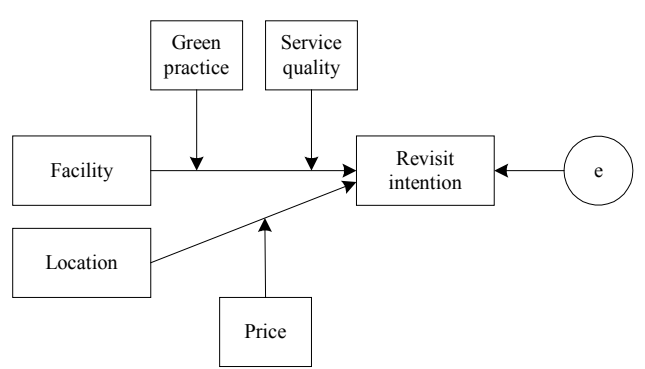

Figure 4. Model 4

Model 5. The influence of facility moderated by service quality and green practice, location moderated by price to revisit intention. Figure 5 shows the relationship of this model. The equation for this model is: $f(y)=f\left(x_{-} f q g p, x_{-} l\right)$

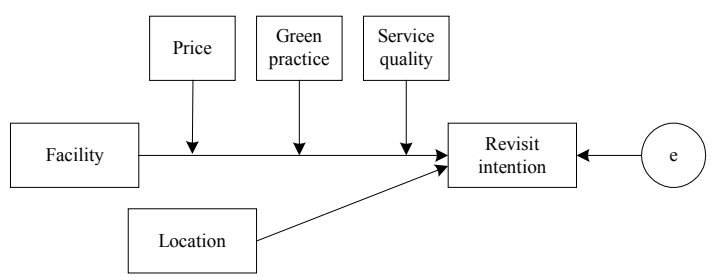

Figure 5. Model 5

The performance models are tested by using three model selection methods, i.e. $\mathrm{R}^{2}, \mathrm{R}^{2}$-adjusted and Akaike Information Criterion (AIC). Generally, the addition of parameter increases $\mathrm{R}^{2}$. But, $\mathrm{R}^{2}$ is unable to detect the number of parameters. Therefore, $\mathrm{R}^{2}$-adjusted and AIC, which are more sensitive to the addition of the parameter, are implemented in this study. The normality of residual, its heteroscedasticity and its autocorrelation, are tested in this study. Normality test of residual is tested by using Kolmogorov-Smirnov normality test. Durbin-Watson test is implemented for checking heteroscedasticity of the residual. Meanwhile, the autocorrelation of the residual is detected by using the White test. The occurrence of multicollinearity among independent variable in the model is checking by using Vector Inflation Factor (VIF).

\section{METHOD}

This study is investigated the willingness of Indonesian customers to revisit a green hotel in central Surakarta. The data is collected through self-administered structured questionnaire, which was distributed online to the green hotel custo- 
mers. Six variables applied in this study are quality service, facility, price, location, green practice offered by the hotel and revisit intention. Those variables were developed from many literatures which are related to green hotel visit and revisit intention.

Thurston method is applied in this study to measure the variable (Effendi \& Tukiran, 2012). But, scales for measuring the items within the variables are using 1 to 10 . This scale is chosen to avoid the discreet value of ordinal data which is commonly used in the measurement. Meanwhile, this study implementing multiple linear regression analysis that should have continues data, not discreet data, to meet the regression analysis assumption. The variables, then, were assessed for their validity and reliability. Product moment correlation was implemented for the validity test, whilst Cronbach Alpha is implemented for the reliability test.

Since this study investigates the relationship among six proposed variables, Moderated Multiple Regression (MMR). This method is implemented as theoretically investigated that there is an interaction among independent variables tested in this study. MMR was commonly used by marketer researchers (Irwin \& Mcclelland, 2001). However, multicollinearity may arise from the interaction between variables. Some MMR scholars argue that multicollinearity produced by MMR is an illusion (Disatnik \& Sivan, 2016). So, it will not create multicollinearity. The estimation of MMR was conducted by using Minitab software.

\section{RESULT AND DISCUSSION}

\section{Respondent profiling}

The respondents were involved in this study are 131. They were Indonesian customers of Rumah Turi, a green hotel which is located in the city centre of Surakarta. They came from 31 cities in Indonesia. About $59.5 \%$ of the respondents were female. They were mostly aged around 20 to 42 years old. About $20.6 \%$ of them were university students and $14.5 \%$ of them were entrepreneurs. Most of them, $41.9 \%$, were staff of private companies.

Table 1. Validity and reliability test

\begin{tabular}{|c|c|c|c|}
\hline Variabel & Item & Validity test & Reliability test \\
\hline \multirow[t]{5}{*}{ Quality } & Staff provides services as the promise & 0.898 & 0.931 \\
\hline & Helpful staff for complain & 0.906 & \\
\hline & Safety in transaction & 0.892 & \\
\hline & Staff understand the costumer need & 0.885 & \\
\hline & Well appearance and professional staff & 0.844 & \\
\hline \multirow[t]{5}{*}{ Facility } & Good service of restaurant & 0.854 & 0.919 \\
\hline & Parking availability & 0.890 & \\
\hline & Laundry service & 0.918 & \\
\hline & Easy transportation service & 0.883 & \\
\hline & Internet accessible & 0.826 & \\
\hline \multirow[t]{3}{*}{ Price } & Price meet the quality & 0.921 & 0.900 \\
\hline & Similar price with other hotel & 0.899 & \\
\hline & Price meet the benefit & 0.920 & \\
\hline \multirow[t]{4}{*}{ Location } & Easy to access & 0.860 & 0.790 \\
\hline & No traffic jam & 0.755 & \\
\hline & Comfortable & 0.889 & \\
\hline & Strategic & 0.669 & \\
\hline \multirow[t]{5}{*}{ Green practice } & Green concept & 0.872 & 0.899 \\
\hline & Park and trees & 0.817 & \\
\hline & Solar water heating & 0.866 & \\
\hline & Bins & 0.779 & \\
\hline & Energy saving lighting & 0.843 & \\
\hline \multirow[t]{3}{*}{ Revisit intention } & I have willingness to revisit & 0.934 & 0.927 \\
\hline & I have a plan to revisit & 0.945 & \\
\hline & I have an effort to revisit & 0.923 & \\
\hline
\end{tabular}


Table 2. Descriptive statistics and correlation analysis

\begin{tabular}{|c|c|c|c|c|c|c|c|c|}
\hline \multirow[t]{2}{*}{ Variable } & \multirow[t]{2}{*}{ Mean } & \multirow[t]{2}{*}{ SD } & \multicolumn{6}{|c|}{ Correlation } \\
\hline & & & Price & Facility & $\begin{array}{l}\text { Service } \\
\text { quality }\end{array}$ & Location & $\begin{array}{l}\text { Green } \\
\text { practice }\end{array}$ & $\begin{array}{l}\text { Revisit } \\
\text { intention }\end{array}$ \\
\hline Price & 7.87 & 0.109 & 1 & 0.537 & 0.498 & 0.426 & 0.537 & 0.525 \\
\hline Facility & 7.53 & 0.119 & & 1 & 0.564 & 0.393 & 0.643 & 0.587 \\
\hline Service quality & 8.21 & 0.115 & & & 1 & 0.463 & 0.536 & 0.523 \\
\hline Location & 8.13 & 0.095 & & & & 1 & 0.388 & 0.457 \\
\hline Green practice & 8.38 & 0.106 & & & & & 1 & 0.576 \\
\hline Revisit intention & 8.06 & 0.119 & & & & & & 1 \\
\hline
\end{tabular}

\section{Data testing and descriptive analysis}

Validity and reliability test of variables are presented in Table 1. It is apparent, all items in each variable have correlation test more than 0.6 , whilst alpha Cronbach of variables are higher than 0.79. It can be inferred that the item is valid and reliable.

Table 2 is a descriptive analysis of variables. Mean of the variable in this study is the average mean of the item in each variable. From the table, it is clearly seen that the mean rate of green practice and service quality are higher among other variables. Interestingly, the customer rated high (8.06) to revisit intention even though they valued 7.5 for facility and 7.8 for price. The hotel set a higher price in comparison to other hotels, as the location of the hotel is in the middle of the city and it is near the centre of heritage and shopping centre.

Table 2 also provides the correlation among variables. This is an indicator of the relationship among variables. The higher correlation means there is a high relationship among two variables. In the regression analysis, it is expected that independent variables and dependent variable have high correlation, but interrelation among independent variables should be avoided because it creates multicollinearity.

This study shows that there is a high relationship between independent variables, i.e. price, facility, quality, location and green practice, and behavioural intention. However, it is also apparently seen that high correlation also occurs to independent variables. Price, facility and green practice have the highest correlation. Similarly, green practice has a high relation to price and service quality. These are the indicators of multicollinearity in the model, which may bias for being estimated. As previously mentioned, the model will be tested in this study have been described above.

\section{Model analysis}

The result of multiple regression and MMR analysis of the models are presented in Table 3.
Three model selection methods using $R^{2}, R^{2}$-adjusted and AIC as well as diagnostic checking of regression analysis is presented in Table 3 .

Model 1 is developed to identify individual influence of each variable to revisit intention. Apparently, regression analysis of Model 1 shows that facility, location and green practice in $\mathrm{Ru}-$ mah Turi influences visitors to have revisit intention. Insignificant parameter in the model creates overestimation. Therefore, it should be modified (Schumacker \& Lomax, 2004). The modification model is Model 1.a, where facility, location and green practice are the independent variables which determine revisit intention. The equation for this model is: $f(y)=f\left(x \_f, x \_1, x \_g\right)$

This modification model result in all significant variables. But, there are problems in checking the normality and autocorrelation residual of the models. The greatest influence of customer to have revisit intention is green practice $(0.322)$ in the hotel, and it is followed by facility $(=0.315)$ provided by the hotel management. However, this model does meet analysis assumption in terms of normality and autocorrelation of residual.

$\mathrm{Ka}$ et al. (2016) argue that restaurant is an attribute of service quality. Tangible of the hotel, such as physical appearance and facility are the attribute of service in addition to staff appearance and services (Djunaidi et al., 2006). This is the reason of service quality is incorporated into facility as the moderator variable in Model 1.a. The new model is Model 2.

Regression analysis of Model 2 is available in Table 3. It shows that all variable's parameters are statistically significant at $\alpha=5 \%$. In comparison to Model 1.a, Model 2 resulted a higher of $R^{2}$-adjusted but smaller of AIC. Also, Kolmogorov-Smirnov (K-S) test of Model 1.a does not meet normality assumption ( $\mathrm{p}$-value of K-S test is less than 0.010), while Model 2 has met normality assumption of the regression model with $\mathrm{p}$ value of K-S test is 0.03 . This implies that data of 
this study have sufficiently proven the hypothesis of the intention of customer revisit is influenced by location and facility which is moderated by service quality.

The argument develops model 3 that location increases the price of the hotel room (Chica-olmo et al., 2020; Masiero et al., 2019; Rigall-i-torrent et al., 2011). The result of regression analysis in Table 3 shows that all variable's parameters are statistically significant at $\alpha=5 \%$. The most influence variable to revisit intention of the customer is green practice of the hotel with is equal to 0.257 . In terms of model assumption, Model 3 is better at K-S normality test in comparison to Model 2. It has resulted in $p$-value of $\mathrm{K}-\mathrm{S}$ is equal to 0.043 . Model 3 also has a higher $R^{2}$ and AIC. This means Model 3 is better model than Model 2.

Model 4 incorporating green practice and service quality into facility in Model 3. This model is developed because there is some evidence that green practice which incorporated to service

Table 3. Model testing

\begin{tabular}{|c|c|c|c|c|c|c|c|c|c|}
\hline \multirow{2}{*}{ Model } & \multirow{2}{*}{ Parameter } & \multirow{2}{*}{ p-value } & \multirow[b]{2}{*}{$\mathbf{R}^{2}$} & \multirow[b]{2}{*}{$\mathbf{R}^{2}$-adj } & \multirow[b]{2}{*}{ AIC } & \multicolumn{3}{|c|}{ Diagostic Checking } & \multirow[b]{2}{*}{ ACF } \\
\hline & & & & & & VIF & d & K-S & \\
\hline Model 1: & & & 48.01 & 45.93 & 283.61 & & 1.947 & 0.058 & No \\
\hline \multirow[t]{6}{*}{ Constanta } & 0.285 & 0.717 & & & & & & & - \\
\hline & 0.131 & 0.142 & & & & 1.77 & & & \\
\hline & 0.233 & $0.012^{* *}$ & & & & 2.03 & & & \\
\hline & 0.169 & $0.066^{*}$ & & & & 1.67 & & & \\
\hline & 0.198 & $0.039 * *$ & & & & 1.38 & & & \\
\hline & 0.240 & $0.020^{* *}$ & & & & 1.96 & & & \\
\hline Model 1.a: & & & 45.23 & 43.94 & 281.38 & & 1.939 & $<0.010$ & Lag 2 \\
\hline \multirow[t]{4}{*}{ Constanta } & 0.734 & 0.348 & & & & & & & \\
\hline & 0.315 & $0.000 * * *$ & & & & 1.78 & & & \\
\hline & 0.277 & $0.003^{* * *}$ & & & & 1.23 & & & \\
\hline & 0.322 & $0.001^{* * *}$ & & & & 1.77 & & & \\
\hline Model 2: & & & 46.96 & 45.70 & 280.78 & & 1.917 & 0.030 & Lag 2 \\
\hline \multirow[t]{4}{*}{ Constanta } & 2.054 & 0.013 & & & & & & & \\
\hline & 0.212 & $0.025^{* *}$ & & & & 1.33 & & & \\
\hline & 0.275 & $0.006^{* * *}$ & & & & 1.86 & & & \\
\hline & 0.032 & $0.000^{* * *}$ & & & & 2.09 & & & \\
\hline Model 3: & & & 46.70 & 45.44 & 281.06 & & 1.933 & 0.043 & Lag 2 \\
\hline \multirow[t]{4}{*}{ Constanta } & 3.023 & 0.000 & & & & & & & \\
\hline & 0.016 & $0.035^{* *}$ & & & & 1.81 & & & \\
\hline & 0.257 & $0.012^{* *}$ & & & & 1.91 & & & \\
\hline & 0.029 & $0.000 * * *$ & & & & 2.37 & & & \\
\hline Model 4: & & & 43.27 & 42.38 & 282.68 & & 1.965 & 0.046 & $\operatorname{Lag} 2$ \\
\hline \multirow[t]{3}{*}{ Constanta } & 4.893 & $0.000^{* * *}$ & & & & & & & \\
\hline & 0.019 & $0.013^{* *}$ & & & & 1.79 & & & \\
\hline & 0.004 & $0.000^{* * *}$ & & & & 1.79 & & & \\
\hline Model 5: & & & 41.25 & 40.23 & 285.91 & & 1.928 & 0.037 & Lag 2 \\
\hline \multirow[t]{3}{*}{ Constanta } & 4.33600 & $0.000^{* * *}$ & & & & & & & \\
\hline & 0.09600 & $0.013^{* *}$ & & & & 1.30 & & & \\
\hline & 0.00005 & $0.000 * * *$ & & & & 1.30 & & & \\
\hline
\end{tabular}

Note: ${ }^{*}$ is significant at $\alpha=10 \%,{ }^{* *}$ is significant at $\alpha=5 \%$, whilst ${ }^{* * *}$ is significant at $\alpha=1 \%$. 
quality influence behavioral intention (Lee et al., 2018; Robinot \& Gionnelloni, 2010). The model analysis is presented in Table 3. It shows that incorporating price into location and incorporating green practice and service quality into facility have resulted significant parameters at $\alpha=5 \%$. This model (Model 4) also results higher AIC and K-S normality $\mathrm{p}$-value than Model 3, but it still have a similar problem with autocorrelation of residual.

The last model is Model 5 which is developed by considering the argument that facility is included as the tangible factors of service quality and green practice should be incorporated into service of the hotel. The analysis of Model 5 which is presented in Table 3 shows that all parameters are significant, even the autocorrelation among residual are have occurred. But, the influence of moderation of green practice, price and service quality into facility is very small $(=0.00005)$.

\section{Discussion}

This study has proven that, individually, price does not influence revisit intention, but green practice and followed by facility of hotel influence customer revisit intention. This study is in contrast to the study of Njite et al. (2017) who found that price is the higher attributes that determine costumers to visit the hotel, whilst location is the third attributes and green practice is last attributed preferred by the costumers. Rumah Turi is popular with green image. This is the reason why Rumah Turi customers attracted by its green practice.

Some scholars has proven that service quality was unable to influence behavioral intention to green hotel directly, but there is consumer satisfaction as the result of service quality (Lisa \& Mattila, 2014). This may apply to this study because by using our data, we are unable to prove that service quality influences customer intention to revisit. It should be satisfaction variable as the mediator relationship between service quality and behavioral intention.

Nevertheless, we believe that service quality and price of Rumah Turi influence customer to revisit. Some scholar such as Wilkins et al. (2007) shows that quality service in a hotel entails of physical product which refers to quality of room and valet parking, service experiences which more focus on quality service by the staff, and quality of food and beverage. Moreover, according to Ka et al. (2016), foods and beverages service as one of item in service quality of the hotel. In this study, restaurant is categorized in facilities of the hotel. Hence, moderating quality service into facility is the right decision. This is, then, Model 4 and 5 are developed. By moderating service quality and green practice in a hotel facility variable in Model 4 it seems that this study supports Robinot and Gionnelloni (2010) study that says green practice should be incorporated in service quality. This model also supported the argument that the combination of price and location attracts customer intention to visit/revisit.

\section{CONCLUSION AND RECOMMENDATION}

This study proven that, by using Rumah Turi customer data, facility, location and green practice influence revisit intention. The determinant of price and service quality to revisit intention is insignificant. However, this study found three suggestion best models. First model is that price as the moderator of location, service quality as the mediator of facility, and green practice have influenced significantly to revisit intention to Rumah Turi. Second model is service quality and green practice are the moderator of facility along with price as the moderator of location influence revisit intention to Rumah Turi. The last model is price, green practice, service quality are the moderator of facility along with location have influenced revisit intention.

However, this study was only supported by 131 data from an online customer survey. Data which was reported by Rumah Turi shows that a monthly number of room occupancy from 2015 to 2017 was about 100 to 300 rooms. It may have more customers should be involved. Research with a higher number of samples will be more convincing.

\section{REFERENCES}

Adam, I., \& Amuquandoh, F. E. (2013). Dimensions of Hotel Location in the Kumasi Metropolis, Ghana. Tourism Management Perspectives, 8, 1-8.

Al-Aomar, R., \& Hussain, M. (2017). An Assessment of Green Practices in a Hotel Supply Chain: A Study of USE Hotels. Journal of Hospitality and Tourism Management, 32, 71-81.

Alonso-Almeida, M., Robin, C. F., Pedroche, M. S. C., \& Astorga, P. S. (2016). Revisiting Green Practices in the Hotel Industry: A Comparison between Mature and Emerging Destinations. Journal of Cleaner Production, 140, 1415-1428.

Arafat, S., \& Syamsiyah, N. R. (2013). Performansi Greenship Building pada Rumah Tiri di Surakarta (Penekanan pada Water Conservation dan Material Resource and Cycle). Sinetika, 13(1), 11-18.

Baker, M. A., Davis, E. A., \& Weaver, P. A. (2013). Eco-friendly Attitudes, Barriers to Participation, and Differences in Behavior at Green Hotels. Cornell Hospitality Quarterly, 55(1), 89-99.

BPS Kota Surakarta. (2018). Statistik Tingkat Penghu- 
nian Kamar Hotel 2018. Surakarta: BPS Kota Surakarta.

Chan, E. S. (2014). Green Marketing: Hotel Customers' Perspective. Journal of Travel \& Tourism Marketing, 31(8).

Chan, E. S. W. (2013). Managing Green Marketing: Hong Kong Hotel Managers' Perspective. International Journal of Hospitality Management, 34, 442-461.

Chen, Y., Shen, H., Zhong, Q., Chen, H., Huang, T., Liu, J., \& Tao, S. (2016). Transition of Household Cookfuels in China from 2010 to 2012. Applied Energy, 184, 800-809.

Chica-Olmo, J., González-Morales, J. G., \& ZafraGómez, J. L. (2020). Effects of Location on Airbnb Apartment Pricing in Málaga. Tourism Management, 77(September 2019), 103-981.

Colby, J. D., Mulcahy, K. A., \& Wang, Y. (2000). Modeling Flooding Extent from Hurricane Floyd in the Coastal Plains of North Carolina. Environmental Hazards, 2(4), 157-168.

Deraman, F., Ismail, N., Arifin, A. I. M., \& Mostafa, M. I. A. (2017). Green Practices in Hotel Industry: Factors Influencing the Implementation. Journal of Tourism, Jospitality \& Culinary Arts (JTCA), 9(2), 305-316.

Disatnik, D., \& Sivan, L. (2016). The Multicollinearity Illusion in Moderated Regression Analysis. Marketing Letter, 27(2), 403-408.

Djunaidi, M., Setiawan, E., \& Hariyanto, T. (2006). Analisis Kepuasan Pelanggan dengan Pendekatan Fuzzy Service Quality dalam Upaya Peningkatan Kualitas Pelayanan. Jurnal Ilmiah Teknik Industri, 4(3), 139-146.

Effendi, S., \& Tukiran. (2012). Metode Penelitian Survey (Edisi Revi). Jakarta: LP3ES.

Fang, L., Li, H., \& Li, M. (2019). Does Hotel Location Tell a True Story? Evidence from Geographically Weighted Regression Analysis of Hotels in Hong Kong. Tourism Management, 72(July 2018), 78-91.

Graci, S., \& Dodds, R. (2008). Why Go Green? The Business Case for Environmental Commitment in the Canadian Hotel Industry. Anatolia: An International Journal of Tourism and Hospitality Research, 19(2), 251-270.

Han, H. (2015). Travelers' Pro-Environmental Behavior in a Green Lodging Context: Converging Value-Belief-Norm Theory and the Theory of Planned Behavior. Tourism Management, 47, 164-177.

Han, H., Hsu, L. T. (Jane), \& Lee, J. S. (2009). Empirical Investigation of the Roles of Attitudes Toward Green Behaviors, Overall Image, Gender, and Age in Hotel Customers' Eco-Friendly Decision-Making Process. International Journal of Hospitality Management, 28(4), 519-528.

Han, H., \& Jin, H. (2015). Hotel Customers' Environmentally Responsible Behavioral Intention: Impact of Key Constructs on Decision in Green Consumerism. International Journal of Hospitality Management, 45, 22-33.
Han, H., \& Kim, Y. (2010). An Investigation of Green Hotel Customers' Decision Formation: Developing an Extended Model of the Theory of Planned Behavior. International Journal of Hospitality Management, 29(4), 659-668.

Han, H., Kim, Y., \& Kim, E. K. (2011). Cognitive, Affective, Conative, and Action Loyalty : Testing the Impact of Inertia. International Journal of Hospitality Management, 30, 1008-1019.

Hsiao, T., Chuang, C., Kuo, N., \& Yu, S. M. (2014). Establishing Attributes of an Environmental Management System for Green Hotel Evaluation. International Journal of Hospitality Management, 36, 197-208.

Hu, N., Zhang, T., Gao, B., \& Bose, I. (2019). What Do Hotel Customers Complain About? Text Analysis Using Structural Topic Model. Tourism Management, 72, 417-426.

Irwin, J. R., \& Mcclelland, G. H. (2001). Misleading Heuristics and Moderated Multiple Regression Models. Journal of Marketing Research, 17(2), 100-109.

Ka, I., Lai, W., \& Hitchcock, M. (2016). A Comparison of Service Quality Attributes for StandAlone and Resort-Based Luxury Hotels in Macau : 3-Dimensional Importance- Performance Analysis. Tourism Management, 55, 139-159.

Kandampully, J., \& Suhartanto, D. (2000). Customer Loyalty in the Hotel Industry: The Role of Customer Satisfaction and Image. International Journal of Contemporary Hospitality Management, 12(6), 346-351.

Kasim, A. (2004). BESR in the Hotel Sector: A Look at Tourists' Propensity toward Environmentally and Socially Friendly Hotel Attributes in Pulau Pinang, Malaysia. International Journal of Hospitality \& Tourism Administration, 5(2), 61-83.

Kiatkawsin, K., \& Han, H. (2017). Young Travelers' Intention to Behave Pro-Environmentally: Merging the Value-Belief-Norm Theory and the Expectancy Theory. Tourism Management, 59, 76-88.

Lee, J., Hsu, L. J., Han, H., \& Kim, Y. (2010). Understanding How Consumers View Green Hotels: How a Hotel's Green Image Can Influence Behavioural Intentions. Journal of Sustainable Tourism, 18(7), 901-914.

Lee, S., Sun, K., Wu, L. L., \& Xiao, Q. (2018). A Moderating Role of Green Practices on the Relationship between Service Quality and Customer Satisfaction : Chinese Hotel Context. Journal of China Tourism Research, 14(1), 42-60.

Lisa, Y., \& Mattila, A. S. (2014). Improving Consumer Satisfaction in Green Hotels: The Roles of Perceived Warmth, Perceived Competence, and CSR Motive. International Journal of Hospitality Management, 42, 20-31.

Masiero, L., Yang, Y., \& Qiu, R. T. R. (2019). Understanding Hotel Location Preference of Customers : Comparing Random Utility and Random Regret Decision Rules. Tourism Management, 73(April 2018), 83-93. 
Merli, R., Preziosi, M., Acampora, A., \& Ali, F. (2019). Why Should Hotels Go Green? Insights from Guests Experience in Green Hotels. International Journal of Hospitality Management, 81(April), 169-179.

Millar, M. (2009). A Choice model approach to business and leisure traveler $\hat{a} €^{T M} s$ preferences for green hotel attributes. University of Nevada, Las Vegas.

Millar, M., \& Baloglu, S. (2008). Hotel Guests' Preferences for Green Hotel Hotel Guests' Preferences for Green Hotel Attributes. Hospitality Management.

Millar, M., Mayer, K. J., \& Baloglu, S. (2012). Importance of Green Hotel Attributes to Business and Leisure Travelers. Journal of Hospitality Marketing \& Management, 21(4), 394-413.

Nimri, R., Patiar, A., \& Kensbock, S. (2017). A Green Step Forward: Eliciting Consumers' Purchasing Decisions Regarding Green Hotel Accommodation in Australia. Journal of Hospitality and Tourism Management, 33, 43-50.

Njite, D., Schaffer, J., Njite, D., \& Schaffer, J. (2017). Revisiting Attributes : How Important is Green in the Consumer Selection of Hotel Rooms? International Journal of Hospitality \& Tourism Administration, 18(2), 1-26.

Perera, P., \& Vlosky, R. (2013). How Previous Visits Shape Trip Quality, Peceived Value, Satisfaction, and Future Behavioral Intentions: The Case of Forest-Based Ecotourism in Sri Lanka. International Journal of Sport Management Recreation \& Tourism, 11, 1-24.

Rahman, I., \& Reynolds, D. (2016). Predicting Green Hotel Behavioral Intentions Using a Theory of Environmental Commitment and Sacrifice For the Environment. International Journal of Hospitality Management, 52, 107-116.

Reagan, H. A., Anam, C., Hastuti, A., Setiyawati, N., Pratiwi, A. I., Larasaty, P., \& Handika, F. (2018). Indikator Tujuan Pembangunan Berkelanjutan (TPB) Indonesia 2018. Jakarta: Badan Pusat Statistik.

Rigall-I-Torrent, R., Fluvià, M., Ballester, R., Saló,
A., Ariza, E., \& Espinet, J. (2011). The Effects of Beach Characteristics and Location with Respect to Hotel Prices. Tourism Management, 32(5), 1150-1158.

Robinot, E., \& Gionnelloni, J.-L. (2010). Do Hotels' "Green" Attributes Contribute to Customer Satisfaction? Journal of Services Marketing, 24, 157-169.

Said, A., Budiati, I., Reagan, H. A., Riyadi, A. H., Anam, C., \& Larasaty, P. (2016). Potret Awal Tujuan Pembangunan Berkelanjutan 9 (Sustainable Development Goals) di Indonesia. Jakarta: Penerbit Badan Pusat Statistik.

Saló, A., Garriga, A., Rigall-I-Torrent, R., Vila, M., \& Fluvià, M. (2014). Do Implicit Prices for Hotels and Second Homes Show Differences in Tourists' Valuation for Public Attributes for Each Type of Accommodation Facility? International Journal of Hospitality Management, 36, 120-129.

Schumacker, R. E., \& Lomax, R. G. (2004). A Beginner's Guide to Structural Equation Modelling. New Jersey: Lawrence Erlabaum Associates.

Soegijanto, F. (2014). Kajian Terapan Eko Interior pada Rumah Turi Hotel di Surakarta. Dimensi Interior, 12(1), 31-37.

Souza, C. D. (2007). Examination of Environmental Beliefs and its Impact on the Influence of Price, Quality and Demographic Characteristics with Respect to Green Purchase Intention. Journal of Targeting, Measurement and Analysis for Marketing, 15(2), 69-78.

Valentin, M., \& O'Neill, J. W. (2019). The Value of Location for Urban Hotels. Cornell Hospitality Quarterly, 60(1), 5-24.

Verma, V. K., \& Chandra, B. (2018). An Application of Theory of Planned Behavior to Predict Young Indian Consumers' Green Hotel Visit Intention. Journal of Cleaner Production, 172, 1152-1162. http://doi.org/10.1016/j.jclepro.2017.10.047

Wilkins, H., Merrilees, B., \& Herington, C. (2007). Towards an Understanding of Total Service Quality in Hotels. Hospitality Management, 26, 840-853. 